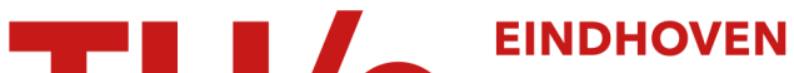 \\ UNIVERSITY OF \\ TECHNOLOGY
}

\section{Homogeneous versus heterogeneous zeolite nucleation}

\section{Citation for published version (APA):}

Dokter, W. H., Garderen, van, H. F., Beelen, T. P. M., Santen, van, R. A., \& Bras, W. (1995). Homogeneous versus heterogeneous zeolite nucleation. Angewandte Chemie - International Edition, 34(1), 73-75. https://doi.org/10.1002/anie.199500731

DOI:

10.1002/anie.199500731

Document status and date:

Published: 01/01/1995

\section{Document Version:}

Publisher's PDF, also known as Version of Record (includes final page, issue and volume numbers)

\section{Please check the document version of this publication:}

- A submitted manuscript is the version of the article upon submission and before peer-review. There can be important differences between the submitted version and the official published version of record. People interested in the research are advised to contact the author for the final version of the publication, or visit the $\mathrm{DOI}$ to the publisher's website.

- The final author version and the galley proof are versions of the publication after peer review.

- The final published version features the final layout of the paper including the volume, issue and page numbers.

Link to publication

\section{General rights}

Copyright and moral rights for the publications made accessible in the public portal are retained by the authors and/or other copyright owners and it is a condition of accessing publications that users recognise and abide by the legal requirements associated with these rights.

- Users may download and print one copy of any publication from the public portal for the purpose of private study or research.

- You may not further distribute the material or use it for any profit-making activity or commercial gain

- You may freely distribute the URL identifying the publication in the public portal.

If the publication is distributed under the terms of Article 25fa of the Dutch Copyright Act, indicated by the "Taverne" license above, please follow below link for the End User Agreement:

www.tue.nl/taverne

Take down policy

If you believe that this document breaches copyright please contact us at:

openaccess@tue.nl

providing details and we will investigate your claim. 
refinement gave almost identical parameters and $R$ values. Further details of the crystil structure investigation may be obtained from the Fachinformationszentrum Karlsruhe, D-76344 Eggenstein-Leopoldshafen (Germany) on quoting the depository numbers CSD-401026 (room-temperature form) and CSD401027 (low-temperature form)

[8] (C. J. vatn Loon, J. D. Ijdo, Ata Crystallogr. S't' B 1975, 31, $770-773$

[9] P. W. Selwood, Magnetochemistry. Interscience, New York. 1956.

[10] H. Lucken. personal Communication; H. Lueken, L. Maque, Z. Anorg. Alig. $(\mathrm{h} / \mathrm{m})$ 1982,490, 64-76.

[11] P. Ciütlich Angen. Chom. 1994, 106. 2109-2141; Angen. Chem. Int. Ed. Engl. 1994. $33,2024,2054$

[12] W. Klemm. L. Grimm. Z. Anorg. Allg. Chem. 1942, 249, 198-208, 209 $21 x$.

[13] J. Lewis, D. J. Machin. I. E. Newnham, R. S. Nyholm, J. Chem. Soc. 1962. 20362041 .

\section{Homogeneous versus Heterogeneous Zeolite Nucleation}

Wim H. Dokter, Harold F. van Garderen, Theo P. M. Beelen. ${ }^{*}$ Rutger A. van Santen, and Wim Bras

A question of considerable debate in zeolite synthesis is the nature of the precursor gel from which the zeolite is formed and whether nucleation occurs within the gel or from the mother liquid of the synthesis mixture. ${ }^{[1,2]}$ For the synthesis of ZSM-5 and silicalite considerable evidence supports the hypothesis that crystallization occurs by transformation of the precursor gel. ${ }^{[3,4]}$ On the other hand, it has also been demonstrated that the zeolite can be formed directly from the liquid phase without the intermediacy of a gel phase. ${ }^{[5]}$ Here we report on a silicalite synthesis in which the silicalite crystallites do not nucleate in a separate gel phase, but directly from the liquid phase. Even in this experimental system, in which no gel phase was expected, precursor aggregates were observed with simultaneous, realtime small- and wide-angle X-ray scattering (SAXS-WAXS). These aggregates reorganize in analogy to the heterogeneous reaction mixture before nucleation and subsequent crystallization. ${ }^{[2.6]}$

Time-resolved small- and wide-angle X-ray scattering can be applied to study aggregation, gelation, and crystallization processes under in situ conditions. We recently reported a SAXSWAXS study of the gel morphology changes that occur during silicalite formation in a synthesis mixture with a separate gel phase. We found significant gel transformations before nucleation of silicalite crystallites. The gel morphology could be analyzed in terms of primary particles with a radius of $14 \mathrm{~nm}$ and an initial surface fractal dimension of 2.7. indicating a rough surface, which reorganized into smoother particles during reaction. ${ }^{[2, t]}$ We concluded that nucleation proceeds within the gel.

The simultaneous small- and wide-angle X-ray scattering experiments were performed using beamline 8.2 at the Synchrotron Radiation Source (Daresbury Laboratories, United Kingdom). Details concerning camera geometry and data collection were presented elsewhere. ${ }^{[7]}$ The spatial resolution of the

\footnotetext{
[*] D5, Ir. T. P. M. Beelen, Dr. Ir. W. H. Dokter. Drs, H. F. van Garderen.

Prof. Dr. R. A. Santen

Schuit Institute of Catalysis

Eindhoven University of Technology

P.O. Box 513. NL-5600 MB Eindhoven (Netherlands)

Telefax: Int code $+(40) 455054$

Drs. W. Bris

Daresbury Laboratory

United Kingdom \& Netherlands Organisation for Scientific Research
}

SAXS quadrant detector is $400 \mu \mathrm{m}$, and it can handle up to 300000 counts per second. ${ }^{[8]}$ The WAXS detector is a curved knife-edge INEL detector with a spatial resolution of $50 \mu \mathrm{m}$ and can handle up to 100000 counts per second.$^{[0]}$ The scattering ranges covered are $0.01<Q<0.175 \AA^{-1}$ and $0.8<Q$ $<3.4 \AA^{-1}$ for the SAXS and WAXS detectors, respectively. The SAXS data were corrected for background scattering and solvent using a procedure introduced by Vonk. ${ }^{[10]}$ Fractal dimensions were determined from the parts of the scattering curves where behavior followed the power law, and particle and aggregate sizes were determined from the point of deviation from this behavior. In the determination of the slope of the scattering curve, two possible sources of error may be distinguished. The first is the natural noise present in the data. which is small, however, compared to the error introduced during background subtraction $\left(D_{f} \pm 0.05\right)$. The crystallinity of the final product was determined with in-house XRD, which was calibrated with a fully crystalline sample of silicalite. The relation between a scattering spectrum and the species responsible for the scattering is shown in Figures $1 \mathrm{a}$ and 1 b. For mass fractal aggregates

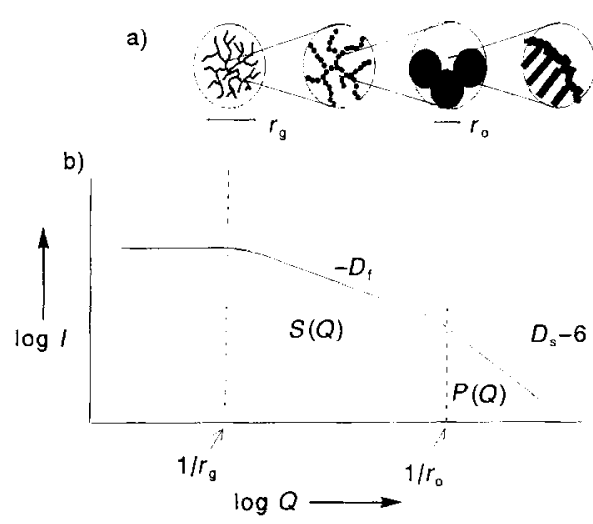

Fig. 1. a) Schematic representation of an aggregate with mass fractal and surface fractal properties; b) the corresponding plot of log $I$ versus log $Q$ of the small-angle scattering spectrum. $S(Q)=$ structure factor, $P(Q)=$ form factor, $l=$ scattered intensity, $Q=$ scattering vector, $D_{\mathrm{f}}=$ mass fractal dimension, $D_{\mathrm{s}}=$ surface fractal dimension, $r_{\mathrm{g}}=$ radius of gyration of the aggregate, $r_{i j}=$ radius of gyration of primary particles.

the scattered intensity will be dominated by the structure factor, providing information about the correlation between the various primary building units present in the aggregates ${ }^{[11]}$ [Eq. (a)]. Here $Q=2 \pi / \lambda \sin (20), \lambda=$ wavelength, $20=$ scattering angle, $P(Q)=$ form factor, $S(Q)=$ structure factor, and $D_{\mathrm{f}}=$ mass fractal dimension.

$I(Q) \sim P(Q) S(Q) \sim S(Q) \sim Q^{-D_{x}}$

On the scale of the primary building units the form factor of the primary building units becomes dominant in the scattering pattern, thus providing information about the surface structure of these units ${ }^{[12]}$ [Eq. (b)], where $D_{s}$, the surface fractal

$I(Q) \sim P(Q) \sim Q^{\left.-16-D_{S}\right)}$

dimension, ranges between 2 and 3 . The surface fractal dimension equals 2 for a nonfractal, completely smooth surface, thus resulting in the well-known Porod relation ${ }^{[13]}$ [Eq. (c)].

$I(Q) \sim Q^{-4}$ 
If $D_{s}$ increases, the roughness of the surface increases. When $D_{s} \rightarrow 3$ and $D_{f} \rightarrow 3$, then a homogeneous distribution of mass and voids (possibly filled) throughout the sample is obtained. ${ }^{[14]}$ Experimentally the parameter $D_{\mathrm{f}}$ (fractal dimension) can be determined from a plot of $\log I(Q)$ versus $\log Q$. The slope of the scattering curve $\alpha$ is equivalent to $-D_{\mathrm{f}}$ for mass fractal scattering and equivalent to $-\left(6-D_{s}\right)$ for surface fractal scattering.

The reaction mixture studied here was prepared from silicic acid powder (Baker $10.2 \mathrm{wt} \%$ water), $\mathrm{NaOH}$ pellets (Merck, $>99 \mathrm{wt} \%$ ) and tetrapropylammonium hydroxide (TPA) (Fluka $20 \mathrm{wt} \%$ ) in the following molar ratios: $\mathrm{SiO}_{2} / \mathrm{TPA}=4.1, \mathrm{SiO}_{2} /$ $\mathrm{NaOH}=11.5, \mathrm{H}_{2} \mathrm{O} / \mathrm{SiO}_{2}=11 .^{[15]} \mathrm{NaOH}$ was added to the TPAOH solution with gentle stirring. The silicic acid was added to the solution and stirred until a homogeneous dispersion was obtained. This solution was heated for approximately $10 \mathrm{~min}$ to obtain a clear synthesis mixture. Water was added to correct for the loss due to evaporation. This synthesis mixture usually remains clear during reaction until crystallization. detectable with standard X-ray diffraction, occurs. ${ }^{[15]}$ The reaction temperature was $120 \mathrm{C} \pm 5^{\circ} \mathrm{C}$.

Our results indicate that in the homogeneous system cluster aggregation occurs before crystallization, in analogy to the heterogeneous system. ${ }^{[2,6]}$ SAXS curves and corresponding schematic aggregate structures are shown in Figures 2 and 3, respectively. As Figures 2 a and 3 b show, the morphology $\left(D_{\mathrm{f}}=2.2\right)$, observed after a reaction time of $5 \mathrm{~min}$ is typical for aggregates condensed according to reaction-limited cluster-cluster aggregation. ${ }^{16]}$ The low rate of reaction is due to the effect of the structure-directing TPA ions. ${ }^{17]}$

The aggregates formed under these conditions have a diameter $d$ of approximately $6.4 \mathrm{~nm}\left(d=2 \cdot r_{\mathrm{g}} ; r_{\mathrm{g}}=\right.$ radius of gyration) These aggregates are composed of primary particles with a radius smaller than $1.6 \mathrm{~nm}$, the upper limit of the $Q$-values of the available SAXS range. These primary particles may be hydrated tetrapropylammonium-silicate clusters. Burkett and Davis have provided evidence for the existence of preorganized organic-inorganic composite structures in the synthesis of ZSM-5. ${ }^{[18]}$ Short-range intermolecular interactions exist between the protons of TPA and silicon atoms of the zeolite precursor phase before development of the long-range order characteristic of the ZSM-5 structure. ${ }^{[18]}$ Other authors observed specific silicate anions in various aqueous silica solutions

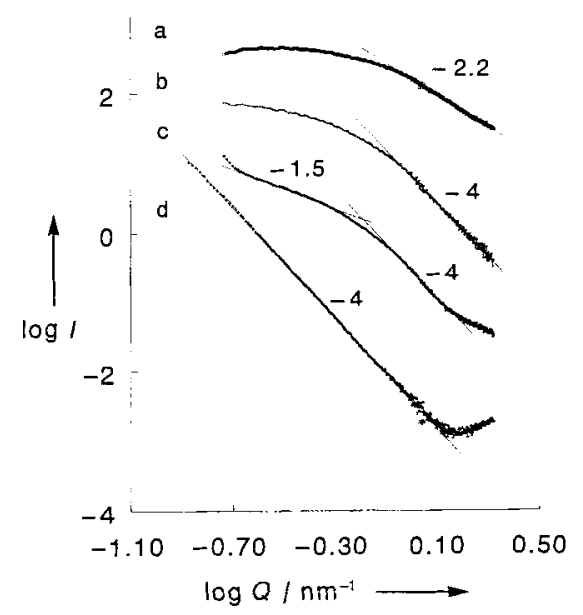

Fig. 2. Plot of $\log l$ versus $\log Q$ of the small-angle X-ray scattering spectra of the clear silicalite synthesis mixture after reaction times of a) $5 \mathrm{~min}$, b) $35 \mathrm{~min}$. c) $75 \mathrm{~min}$, and d) $105 \mathrm{~min}$ a)
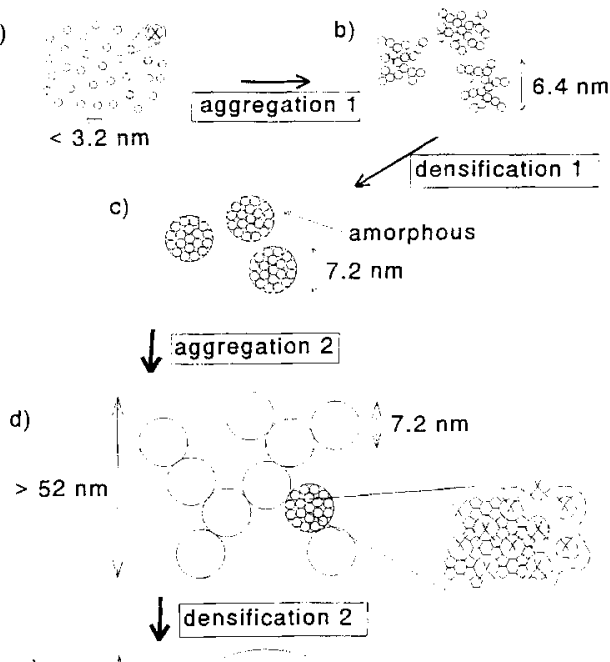

e)

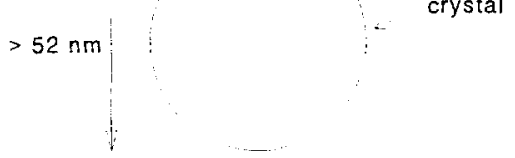

Fig. 3. Mechanism of microstructural random packing, subsequent ordering, and crystallization. a) Silicate/TPA clusters in solution; b) primary fractal aggregates formed from the silicate/TPA clusters $(6.4 \mathrm{~nm}$. Fig. $1 \mathrm{al})$; c) densification of these primary fritctal aggregates (Fig. $1 \mathrm{~b}$ ): d) combination of the densified aggregates into a secondary fractal structure and crystallization (Fig. 1 c); and e) densification of the secondary aggregates and crystal growth.

which may be building blocks for zeolites or precursors of zeolites. $^{[19.20]}$

The observed silica/TPA clusters start to densify (Figs. $2 \mathrm{~b}$ and $3 \mathrm{c}$ ) with time into denser mass fractal aggregates and subsequently into surface fractal aggregates (Fig. 4). After a reaction

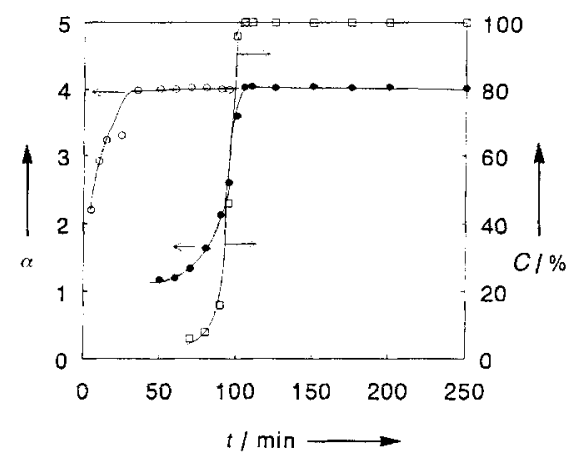

Fig. 4. Plot of crystallinity C (from WAXS) and microstructure (from SAXS) as a function of time $t$. The scattering slopes $x$ obtained with SAXS are divided in the scattering slope at high $Q$ (small madius) (O) and the scattering slope at small Q (large radius) ( ) to clearly demonstrate the consistency between the microstructure and crystallization ()

time of $35 \mathrm{~min}$ at $120^{\circ} \mathrm{C}$ the plot of $\log I(Q)$ versus $\log Q$ shows a Porod slope $(\alpha=-4)$, indicative of a homogeneous dense silica/TPA structure with a smooth surface $\left(D_{\mathrm{s}}=2\right)$. The size of this structure increases only very slightly (to $7.2 \mathrm{~nm}$ ) with time. The fact that it does not decrease upon densification indicates that additional primary particles (TPA surrounded with silicate anions) are transported from solution or other silica aggregates to the densifying cluster. The size of these densified silica/TPA 
particles is approximately equal to 20 silicalite unit cells. After this densification, the 7.2-nm particles aggregate again into a new, secondary fractal aggregate (Figs. $2 \mathrm{c}$ and $3 \mathrm{~d}$ ). The occurrence of crystalline structures is observed simultaneously with WAXS.

Figure 4 shows the time progression of the scattering slope $x$ at large values of $Q$ (small particles) and at small values of $Q$ (large particles or clusters), and the degree of crystallinity as determined with WAXS. The WAXS curves are shown in Figure 5 . From these plots we may conclude that crystallization

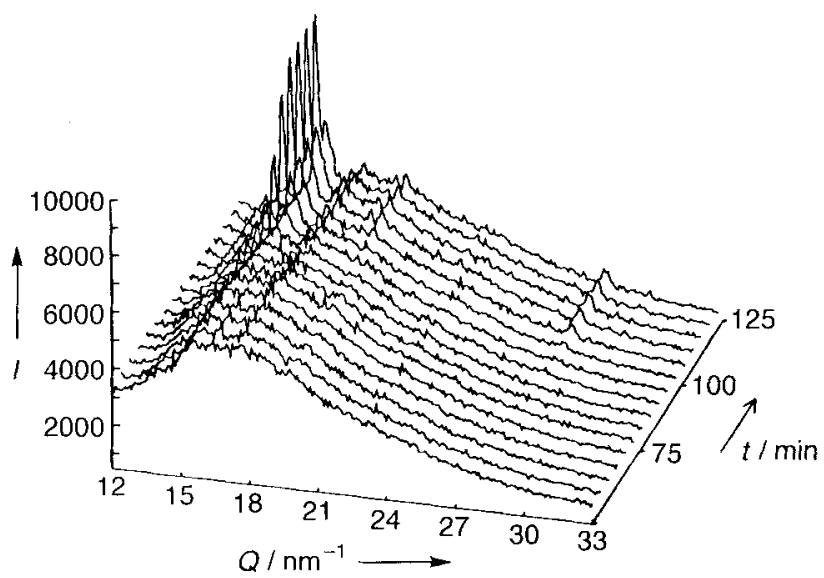

Fig. 5. WAXS spectra of clear silicalite synthesis mixtures demonstrate crystallization heteen 50 and 125 min of reaction. $I=$ intensity. $Q$ = scattering vector $l=$ time.

starts as soon as the dense silica/TPA particles $7.2 \mathrm{~nm}$ in diameter have been formed and aggregation into the larger secondary aggregate starts. Growth of zeolite particles occurs by transformation of the $7.2-\mathrm{nm}$ silica/TPA particles that form the new secondary fractal structure (Fig. 2c). Crystallization occurs again via a surface fractal aggregate (Fig. 4) to a completely smooth (energetically more favorable) structure (Figs. $2 \mathrm{~d}$ and $3 \mathrm{e})$. They grow rapidly to a size larger than the upper size limit (low $Q$-limit) of the available SAXS range $(d>52 \mathrm{~nm})$.

Crystal growth occurs by combination of the densified primary aggregates into kinetically determined secondary aggregates, indicative for growth by combination of already growing nuclei, which subsequently densify into energetically more favorable, dense. smooth particles. These results are in agreement with the results obtained by Twomey et al. who deduced from size distributions of crystals obtained from light-scattering experiments that nucleation is a continuous process and that growth occurs by agglomeration of nuclei. ${ }^{[21]}$

One interesting feature of the results presented here is that also in the homogeneous system a precursor aggregate is formed before crystallization, which is indicative of a gel transformation or gel reorganization mechanism of zeolite crystallization even in a clear silicalite solution. This is in contrast to the direct homogeneous crystallization.

For silicalite synthesized from a gelatinous reaction mixture $^{\mid 2 !}$ it was concluded that crystallization proceeded also according to a gel transformation mechanism. No mass fractality was observed during these experiments. The different silica source (Aerosil 380) leads to very compact amorphous surface fractal precursor particles with a initial particle size of $14 \mathrm{~nm}$. Crystallization, however, starts only after the surface fractal amorphous particles have been transformed into smooth par- ticles with $D_{s}=2$. An analogous feature was observed in this study. The mass fractal aggregate had to transform into smooth, homogeneous, dense structures before crystallization starts. From this we may conclude that homogeneous and heterogeneous crystallization both require an intermediate gel phase before nucleation and crystallization can occur.

In the gel phase nucleation and crystallization occur more slowly than in the homogeneous phase, because the gel formed must first dissolve before a new phase is formed. from which crystallization can occur. This dissolution step is not required in the homogeneous phase, in which the mass transport and subsequent formation of the primary and secondary clusters seem to be the rate-determining steps. Instant crystallization may be achieved when the precursors are prepared in such a way that the desired gel phase for nucleation is obtained directly.

Received: June 30.1994 [Z 7084 [E] German version: Angeri. ( $h^{\prime} m$. 1995, 107. 122

Keywords: crystallization - silicon compounds - structure elucidation $\cdot$ zeolites

[1] M. E. Davis, R. F. Lobo, Chem. Mat'r. 1992, 4, 756

[2] Z. Gabelica, J. B. Nagy, G. Debras, E. G. Derouane, Prece. Int. Zoolite Conf. 6 th $1983,1984,914$.

[3] W. H. Dokter, T. P. M. Beelen, H. F. van Garderen, C. P. I. Rummens, R. A. van Santen, J. D. F. Ramsay, Coll. Surf. A 1994, 85.89

[4] W. Xu, J. Li, W. Li. H. Zhang. B. Liang, Zeolites 1989, 9. 468

[5] L. E. Iton, F. Trouw, T. O. Brun, J. E. Eperson, J. W. White, S. J. Henderson, Langmair 1992. \%. 1045.

[6] W. H. Dokter. T. P. M. Beelen. H. F. van Garderen. R. A. van Santen. W. Bras, G. E. Derbyshire, G. R. Mant. J. Appl. Crystallogr. 1994. 27. 901.

[7] W. Bras, G. E. Derbyshire, A. J. Ryan, G. R. Mant, A. Felton, R. A. Lewis, C. J. Hall, G. N. Greaves. Nucl Instrum. Methods Phis. Res. Se't. A 1993, 326. 587.

[8] R. A. Lewis, N. S. Fore, W. Helsby, C. Hall, A. Jones, B. Parker, I. Sumner. J. S. Worgan, C. Budtz-Jorgensen, Re', Sci. Instrum. 1992. 63 (1). 642.

[9] M. Evain, P. Deniard. A. Jouanneaux, R. Brec, J. Appl. Crystallogr. 1993, 26. 563.

[10] C. G. Vonk. J. Appl. Crystallogr. 1973, 6, 81.

[11] J. E. Martin. A. J. Hurd. J. Appl. Crystallogr. 1987, 20,61

[12] H. D. Bale, P. W. Schmidt, Phys. Rev. Lott. 1983, 53.596

[13] G. Porod, Kollord Z. 1951, 124,83.

[14] D. W. Schaeffer, A. J. Hurd, Acrosol Sci. Technol 1990. I?. 876.

[15] J. Verduyn (PCT), 1992, EP-A02386.

[16] R. Jullien. M. Kolb, J. Phys. A. 1984, 17, L639.

[17] E. M. Flanigan in Intreduction to zeolite science and practice (Eds.: H. Van Bekkum. E. M. Flanigan, J. C. Jansen), Elsevier, Amsterdam, 1991, p. 13.

[18] S. L. Burkett, M. E. Davis, J. Phys. Chem. 1994, in press.

[19] P. W. J. G. Wijnen, T. P. M. Beelen, J. W. de Haan, L. J. M. van de Ven. R. A van Santen, Colloids Surf, 1990, 45, 255.

[20] D. Hoebbel, A. Vargha, B. Fahlke, G. Engelhardt, Z. Anorg. Allg. Chem. 1985, 521,61 .

[21] T. A. M. Twomey, M. Mackay, H. P. C. E. Kuipers, R. W. Thompson, Zeolites 1994, 14. 162 